\title{
Agro-technological Options for Scaling up Crop Productivity, Soil Health and Water Footprint in Rice based Cropping System in Sub-humid (Purvanchal) Region of Uttar Pradesh, India: A Review
}

\author{
Robin Kumar ${ }^{1}$, N.C. Mahajan ${ }^{2}$, R.K. Naresh ${ }^{3}$, S.S. Dhaliwal ${ }^{4}$, Arvind Kumar ${ }^{5}$, \\ M. Sharath Chandra ${ }^{3 *}$, Alok Kumar Pandey ${ }^{1}$, S.F.A. Zaidi ${ }^{1}$, Satendra Kumar ${ }^{6}$, \\ Rajendra Kumar $^{3}$, S.P. Singh ${ }^{6}$ and Sanjeev Kumar Gupta ${ }^{7}$
}

\author{
${ }^{1}$ Department of Soil Science, Narendra Dev University of Agriculture \& Technology, \\ Kumarganj, Ayodhya, U.P., India \\ ${ }^{2}$ Department of Agronomy, Institute of Agricultural Sciences, Banaras Hindu University, \\ Varanasi, U. P., India \\ ${ }^{3}$ Department of Agronomy, ${ }^{6}$ Department of Soil Science, Sardar Vallabhbhai Patel University \\ of Agriculture \& Technology, Meerut, U.P., India \\ ${ }^{4}$ Department of Soil Science, Punjab Agricultural University, Ludhiana, Punjab, India \\ ${ }^{5}$ Department of Agronomy, Barkatullah University Bhopal, M.P., India \\ ${ }^{7}$ Department of Agronomy, Bihar Agricultural University, Sabour, Bhagalpur-Bihar, India
}

*Corresponding author

\section{A B S T R A C T}

\begin{tabular}{|l|}
\hline Key w or d s \\
$\begin{array}{l}\text { Conservation } \\
\text { agriculture, Rice } \\
\text { system productivity, } \\
\text { Water footprint }\end{array}$ \\
\hline Article Info \\
\hline $\begin{array}{l}\text { Accepted: } \\
\text { 20 June } 2019 \\
\text { Available Online: } \\
\text { 10 July } 2019\end{array}$ \\
\hline
\end{tabular}

Rice based production systems in the sub-humid region (Purvanchal) of Uttar Pradesh are traditional, with low yield and low farm income, and they have largely missed out on the benefits of the Green Revolution. To enhance productivity, alleviate environmental and management constraints, and enhance farmers' income in the rice-wheat cropping system of the sub-humid Purvanchal region, Uttar Pradesh, new approaches that are more productive and sustainable need to be developed. Conservation agriculture (CA) together with best management practices (BMP) used in other parts of the IGP offer potential to be extended in the Eastern IGP. A review study of evaluating a range of approaches for enhancing the productivity and soil health of rice based cropping systems in the Purvanchal U.P. The yields of wheat $\left(2.78-3.07 \mathrm{t} \mathrm{ha}^{-1}\right)$ and rice $\left(4.38-6.52 \mathrm{t} \mathrm{ha}^{-1}\right.$ were recorded with the farmers' practices, consisting of intensive tillage (wet tillage or puddling in rice and dry tillage in wheat) followed by inefficient crop establishment practices (transplanting in rice and broadcasting in wheat) with complete removal of crop residues. Different agro-technological Options were adopted in this region to increase the productivity and income of the farmers. Avoiding tillage in wheat and including mungbean increased the yields of wheat and the succeeding rice crop by $10-12 \%$ and 5$8 \%$, respectively. The yields of wheat and rice increased further by $14-16 \%$ and by $10-14 \%$, respectively, with the inclusion of more CA components. Moreover, to include higher cropping intensity and diversification with CA components, 24-26\% higher rice equivalent system productivity was attained. 


\section{Introduction}

Agriculture is facing many challenges in terms of providing food, fibre and other ecosystems services to an ever- increasing population. Specifically, factors such as food security, poverty, competition for land and water resources, developmental activities (industrialization and associated pollution), social and political changes, etc., have increased demand for higher crop productivity. The challenge for agriculture in the $21^{\text {st }}$ century is to implement more sustainable farming systems that are economically viable and accommodate changing technologies and climate. The production of food and fibre continues to increase agriculture's carbon footprint through the increased use of fuel and fertilizers, and contributes to widespread soil and water quality degradation and loss of habitat diversity and biodiversity

Soil is the living outer layer of our planet, a basic natural and non- renewable resource which serves as a medium for plant growth and a habitat where animals and other microorganisms live. Hence research is being conducted all over the world to find the best possible measures to preserve the soils, and with improved management practices use them to enhance agricultural productivity by maintaining environmental quality (Lehman $e t$ al., 2015). Soil forms a main component of the terrestrial ecosystems upon which our well- being and prosperity depend. Enhancement and maintenance of soil productivity is essential to the sustainability of agriculture and for meeting basic needs of a rising population (Bhattacharyya et al., 2014). Under the pressure of increasing food, fodder, feed, fibre and fuel production, soil has been used as substrate for plant growth with considerable dependence on an external supply of plant nutrients, irrigation water, plant protection chemicals etc., without taking into consideration the impact on their capacity to carry out different functions (Bindraban et al., 2012).

Adoption of inappropriate policies and cropping systems along with defective soil management have also resulted in accelerated soil erosion, groundwater quality deterioration, emerging micronutrient deficiencies and adverse impacts on soil biodiversity (Lal, 2000). Earlier, agricultural research focused mainly on a soil function with relation to higher yields and, hence, emphasized management of soil and inputs for enhancing plant nutrient supply. However, in the age of a rapidly degrading environment due to human activity, the role of soil in various environmental processes such as sink and source for pollution is emphasized in various platforms for policymaking (Royal Society 2009). Thus, for higher yields and better quality of food and fodder production from diversified farming systems as well as for better quality of the environment, there is a need for better management of our soil resources by integrating all our efforts related to improving and sustaining its functional quality (Lal and Stewart, 1995).

The scarcity of water, energy and labour, increasing production cost, decreasing farm profitability and climate-change-induced variability are major challenges faced by the farmers in the sub-humid Purvanchal region of Uttar Pradesh. Conservation agriculture (CA) based practices may increase crop productivity and profitability, while conserving natural resources. The green component of WFP contributes large fraction as about 72 percents, while blue and grey component amounted of about 19 and 9 per-cent of the total water consumption, respectively. Supply of blue water is high where the region imparted to semi-arid land. Consequently, a balanced approach between green and blue water use has been recommended to address 
increasing water demand in the future. The review of literature pertaining to present study is discussed under the following heads;

\section{Impact of agro-technological options on crop productivity}

Based on extensive research, the key sustainability factors for high productivity systems in the long run mainly depend on soil health/productivity, which is the function of soil structural stability, hydrological properties, nutrient build-up and retention, efficient nutrient cycling and mobilization to the crop plants. The continuing population increase will result in the reduction of available cultivable land per capita worldwide (Lambin and Meyfroidt, 2011). There is a severe nutrient loss due to top soil erosion besides perpetual organic matter loss (Kuhn 2007). Only 10-11\% of cultivated area is reasonably free from all constraints for crop production. The major causes for soil degradation are: removal of vegetative cover through agricultural clearing; decrease in soil cover through removal of vegetation for fuel wood, fencing, etc.; overgrazing by livestock leading to decrease in vegetative cover and trampling of the soil; agricultural activities like cultivation in steep slopes, farming without anti- erosion measures, improper irrigation and use of heavy machinery; and soil contamination with pollutants such as waste discharges and over use of agrochemicals. Modern farm technologies are more productive on good soils than on poor soils. Technology may sustain yields by making the effects of soil degradation temporary. Yield increase through technology might have been greater if the soil has not been degraded.

The productivity gains of the past have, in fact, slowed down and there is an urgent need for a technological breakthrough to halt this downward trend and sustain productivity in the region. Crop management practices are changing fast. The region has experienced increasing farm mechanization over the last 20 years. Seedbed preparation and harvesting in particular are now commonly undertaken with farm machinery. Strategies for enhancing productivity in rice based cropping systems are (i) reduction of the rice monoculture and diversification of the cropping system with pulses/oilseeds and (ii) enhancing of the input use efficiency in existing double and triple rice based cropping systems through improved technology and management practices (Khayer et al., 2016). Diversification includes vegetables, grain legumes, oilseeds and green manures, which improves the productivity, reduces the pest incidence and enhances the soil fertility and its physical properties by providing a break in soil submergence (Kennedy, 1999). In addition, the balanced fertilizer use, the combined use of organics, the mineral fertilizers and bio-fertilizers and inclusion of summer/ pre kharif crops are the possible optimal agro-techniques for sustainable yields, improved fertilizer use efficiency and restoration of soil fertility in cereal- based cropping systems (Haynes, 2008).

The Eastern Indo Gangetic Plains comprises of Eastern UP, Bihar, West Bengal, and plain parts of Assam (Annonymus, 2001-2011). There is a large gap between potential and productivity of major crops (Singh et al., 2012a). A sizeable part of the cultivated area in eastern region does not have provision for assured irrigation; therefore, even short drought spells adversely affect the stability of agricultural production. The region suffers from various biophysical constraints such as water congestion and flooding during kharif (Singh et al., 2012b). The region is characterized by socio-economic constraints like small and fragmented farm holdings, lowest per capita availability of land, inequitable agrarian structure, resource poor 
farmers, and poor infrastructure facilities like roads, communication power supply, storage and marketing (Singh et al., 2011). The characteristic feature mentioned all together lead to poor system productivity of agricultural as a whole including crop production. Further nutrient use efficiency is also low except nitrogen (40-45\%), other are much lower in the range $(<20 \%)$ (Ali et al., 2012).

Major Rice based cropping systems in eastern Indo-Gangetic Plains (all ecologies included: uplands, midlands and low lands, Rice-PotatoWheat, Rice-Jute/Rice, Rice-Wheat/Boro Rice, Rice-Potato-Winter Maize, Rice-PotatoRice (Boro), Pigeonpea + Greengram-Wheat, Rice-Potato + Maize/Boro Rice and Rice + sesame + Maize + Mungbean (Spring) - Boro Rice. In our understanding, farmers in the eastern IGP diversify the RW systems mainly as a risk management strategy in a region that is prone to drought and floods. Many farmers replace wheat with oilseeds (Brassica juncea Coss. or napus), pulses (pea, Pisum sativum L.), grass pea (Lathyrus spp.), chickpea (Cicer arietinum L.), lentil (Lens culinaris Medic), potato (Solanum tuberosum L.), or sugarcane (Saccharum officinarum L.), and occasionally, rice is replaced by pigeonpea (Cajanus cajan Milsp), maize (Zea mays L.), sunflower (Helianthus annuus L.), soybeans (Glycine max Merr.), and sorghum (Sorghum bicolor Moench). In the eastern IGP, unless wheat is planted during the second half of November, yields decline drastically due to a shortened growing season. Consequently, to improve wheat productivity, it is crucial that rice vacates the fields early in the winter season. Herbicide resistance to isoproturon in Phalaris minor Retz, is not yet a major problem for wheat production in the sub-humid Purvanchal region, Uttar Pradesh.

There are wide variations in soil types, physical infrastructure, and market support systems in the eastern IGP. Irrigated and rainfed agriculture coexist in most districts. This has led to a mosaic pattern of agricultural development. A mentioned earlier, many areas in the eastern IGP are prone to seasonal floods during the monsoon season. The soils in eastern IGP are coarse textured. Acidic soils are also found in the sub-humid eastern plains and are generally deficient in boron.

Most alluvial soils in the IGP are deficient in nitrogen. Deficiencies of phosphorus and zinc are next in order. Because of the micaceous nature of the soils, use of potassium fertilizers has been avoided. There is an urgent need for adoption of appropriate measures to optimize the NPK fertilizer use ratio. The finer textured soils found in lowland ecologies have alluvial "vertic" characteristics leading to excessive cracking on drying or cloddiness when wet, making them often difficult to manage. Such areas in eastern UP have inadequate groundwater development for irrigation, especially critical prior to the main monsoon season rice crop. As a result, farmers begin tillage operations for rice nurseries after the first monsoon shower. As a result of this delay farmers lose nearly $400 \mathrm{~mm}$ of precipitation and leave the rice crop vulnerable to terminal drought at the end of the season.

In general, cropping systems in the IGP are centered on the intensively irrigated ricewheat systems with associated productivity and sustainability problems (Gupta et al., 2003). The problems change, however, from the intensive systems in the Northwest (NWIGP) to those in the Eastern IGP (Balasubramanian et al., 2012), which are characterized by smaller farms, land fragmentation, inadequate irrigation infrastructure, including markets, and greater poverty. These differences reflect significant gradients in the resource base, crop management, and livelihoods across the E-IGP (Erenstein et al., 2007a). 
Cereal production systems in the E-IGP are still largely traditional, and often located in less favourable ecosystems than in the Northwest and Central IGP, resulting in low yield and low farm income (Singh et al., 2009). In these areas, farmers delay wet tillage (puddling) for rice until after the onset of the monsoon, resulting in low rice yields (Gopal and Kumar, 2010) and consequently low wheat yields due to delayed sowing as a result of the late rice harvest (Hobbs and Gupta, 2003).

Puddling for rice destroys soil structure, with adverse effects on the growth and yield of upland crops in the rotation (Gathala et al., 2011; Naresh et al., 2013). In order to alleviate environmental and management constraints and enhance productivity in the rice-wheat cropping system of the E-IGP, new approaches that are more productive and sustainable are needed. Those alternative technologies must conserve the much-needed but gradually declining natural resources while boosting productivity growth in the long run by maintaining soil health and the production environment (Balasubramanian et al., 2012).

Conservation agriculture (CA)-based resource-conserving technologies (RCT) offer particular opportunities in the E-IGP (Singh et al., 2011). Some technologies such as zero/reduced tillage that are widely adopted in the NW-IGP appear to be transferable to the E-IGP after evaluation and modifications. In the E-IGP, where wheat planting is delayed due to late rice harvest, zero/reduced tillage will ensure timely planting. Some of the CAbased component technologies such as laseraided land levelling, zero or reduced tillage (ZT or RT), crop residue retention on the soil surface, and crop diversification have been evaluated individually as alternatives to conventional practices, and positive benefits in terms of enhanced productivity and reduced cost have been reported in a range of agroecological regions (Kumar and Ladha, 2011; Naresh et al., 2018).

Experimental evidence from various production environments in north-eastern IGP of India suggests that conservation agriculture (CA)-based management can have both immediate, e.g. reduced production costs, stabilized crop yield, improved WP (Parihar et al., 2017b) and long term benefits, e.g. higher soil organic matter contents and improved soil quality (Parihar et al., 2016a). Doran and Zeiss, (2000) revealed that soil quality is concerned with the physical and chemical properties of soil; soil health includes biological components of soil along with physical and chemical properties (Fig. 1).

The crop productivity is affected by different physical, chemical and biological properties of the soil (Fig. 1b), which are all interlinked to perform soil functions (Fig. 2a). In physical constraints, the major contributor is soil texture (i.e. composition of soil: clay, sand and silt), which directly affects the soil structure (aggregate size, stability and porosity) and leads to increase or decrease in soil bulk density, hydraulic conductivity, available water capacity and soil erodibility. Organic matter also affects the nutrient availability, its transformation, mobility, adsorption and release by controlling soil buffering capacity. Apart from chemical properties, accumulation of salts in soils also results in salinity, sodicity and alkalinity problems, which render the soil unproductive for crop cultivation.

\section{Impact of Tillage systems on Soil Carbon Aggregates}

Zhang-liu et al., (2013) reported that overall, NT and RT increased the proportions of $>2$ 000 and 250-2000 $\mu \mathrm{m}$ aggregate fractions compared with MP for the 0-20 cm depth. For the $0-5 \mathrm{~cm}$ depth, the total amount of macro- 
aggregate fractions $(>250 \mu \mathrm{m})$ was increased by $65 \%$ in NT and $32 \%$ in RT relative to the MP+R (Fig. 3a). Averaged across all depths, the macro-aggregate fraction followed the order of NT (0.39)>RT (0.30) $>\mathrm{MP}+\mathrm{R}(0.25)=$ MP-R (0.24). However, the proportion of micro-aggregate fraction $(53-250 \mu \mathrm{m})$ was increased with the intensity of soil disturbance. Zhang-liu et al., (2013) also found that the $0-5$ and $5-10 \mathrm{~cm}$ depths, NT and RT had significantly higher total soil C concentration than that of MP-R and MP+R in all aggregate size fractions (Fig. 3b). However, in the 10-20 cm depth, conservation tillage system reduced total $\mathrm{C}$ concentration in the macro-aggregate fraction $(>250 \mu \mathrm{m})$ but not in the micro-aggregate and silt plus clay fractions. The greatest change in aggregate $\mathrm{C}$ appeared in the large macro-aggregate fractions where aggregate-associated $\mathrm{C}$ concentration decreased with depth (Fig. 3b), especially under the NT system.

On the other hand, total C concentrations of the micro-aggregates and silt plus clay fractions were relatively stable. In the $0-5 \mathrm{~cm}$ depth, the $>2000 \mu \mathrm{m}$ fraction had the largest $\mathrm{C}$ concentration under NT, whereas the $<53 \mu \mathrm{m}$ fraction had the lowest $\mathrm{C}$ concentration under the MP-R treatment (Zhang-liu et al., 2013). Similar trend was also observed in the $>2000$ $\mu \mathrm{m}$ and 25-2000 $\mu \mathrm{m}$ fractions (23 vs. $24 \mathrm{~g} \mathrm{C}$ $\mathrm{kg}^{-1}$ aggregates) in the $5-10 \mathrm{~cm}$ depth.

The large macro-aggregte $(>2000 \mu \mathrm{m})$ had relatively lower $\mathrm{C}$ concentration than that in the $>250-2000 \mu \mathrm{m}$ fraction in the $10-20 \mathrm{~cm}$ depth. However, Total C stored in macroaggregates $(>250 \mu \mathrm{m})$ was $73 \%$ higher in RT and $33 \%$ higher in NT compared to the average across both MP treatments. In the 10$20 \mathrm{~cm}$ depth, soil $\mathrm{C}$ stored in the $>2000$, and 250-2000 $\mu \mathrm{m}$ fractions did not differ among the RT, NT and MP+R treatments. The largest $\mathrm{C}$ stock occurred in the 53-250 $\mu \mathrm{m}$ fraction, following the order of $\mathrm{MP}+\mathrm{R}>\mathrm{RT}>\mathrm{MP}-\mathrm{R}>\mathrm{NT}$.
(Fig. 3c). The NT treatment stored less $\mathrm{C}$ than other treatments in the $<53 \mu \mathrm{m}$ fraction.

Fuentes et al., (2009) observed that microaggregates $(53-250 \mu \mathrm{m})$ accounted for more than $50 \%$ of the total soil and were the predominant water-stable size class in both cropping systems and tillage treatments (Fig. $4 \mathrm{a})$. The silt and clay fraction $(<53 \mu \mathrm{m})$ were similar among tillage treatments and soil depth. The proportion of micro-aggregates was lower in NT compared with CT and RT in the 0 - to $5-\mathrm{cm}$ depth in both cropping systems and in the 5 to $10 \mathrm{~cm}$ in the PN-BB system. Both large and small macro-aggregates (>2000 $\mu \mathrm{m}$ and 250-2000 $\mu \mathrm{m}$, respectively) accounted for the lowest proportion of aggregates with $<40 \%$ of the total dry soil mass (Fig. 4a). However, in all the four sites studied greater proportion of large and small macro-aggregates were found in NT compared with CT in the 0- to 5-cm depth except for the small macro-aggregates fraction at SV (Fig. 4a). In the 5- to $10-\mathrm{cm}$ depth, small macroaggregates were greater in NT compared with $\mathrm{CT}$ at PN-BB and AG (Fig. 4a). At SV, greater large macro-aggregates were found in NT compared with CT in all the soil depths.

In the $\mathrm{PN}-\mathrm{BB}$ system, total aggregate $\mathrm{C}$ concentration of the small macro-aggregates differed in the order NT $>\mathrm{RT}>\mathrm{CT}$ for the 0 to 5-cm depth (Fig. 4b). In the same cropping system, micro-aggregate $\mathrm{C}$ concentration under NT was greater than under CT and RT in the $0-$ to $5-\mathrm{cm}$ depth. However, below the 5 -cm depth no differences in total aggregate $\mathrm{C}$ concentrations were observed in this cropping system (Fig. 4b). In the $\mathrm{PN}-\mathrm{BF}$ rotation, similar total aggregate $\mathrm{C}$ concentration among tillage treatments was observed in all the soil layers except in the 0 - to $5-\mathrm{cm}$ depth where greater micro-aggregate $\mathrm{C}$ concentration was observed in NT and CT compared with RT (Fig. 4b). Differences between cropping system were found in the 0 - to 5- and the 5- to 
10-cm depths in the NT treatment where greater total macro-aggregate and microaggregate $\mathrm{C}$ concentrations were observed in the PN-BB system compared with the PN-BF rotation (Fig. 4b).

Fuentes et al., (2009) also found that in the 0to 5-cm depth, neither coarse iPOM C (250$2000 \mu \mathrm{m})$ from small macro-aggregates (250c) nor micro-aggregate iPOM C (53f) were affected by tillage in either cropping systems (Fig. 5a). However, in both cropping systems, the fine iPOM C $(53-250 \mu \mathrm{m})$ concentration of the small macro-aggregates (250f) decreased among tillage treatments in the following order: NT > RT > CT (Fig. 10a). In the 5- to $10-\mathrm{cm}$ and $10-$ to $20-\mathrm{cm}$ depths, no differences were observed among tillage treatments in any iPOM $\mathrm{C}$ size fraction and in any cropping systems (Fig. 5a). Differences between cropping systems were found in the soil surface $(0-5 \mathrm{~cm})$ in the NT treatment where greater coarse and small iPOM C concentrations of the small macro-aggregates were observed in the PN-BB system compared with the PN-BF rotation (Fig. 5a).

In the PN-BB system, greater mineralassociated $\mathrm{C}$ (mSOC) was observed in NT compared with RT in the micro-aggregates in the 0 - to 5-cm depth (Fig. 5b). Below 5-cm depth, no differences in $\mathrm{mSOC}$ were observed in the PN-BB system. The exception was observed in the $10-$ to $20-\mathrm{cm}$ depth where greater mSOC was measured under NT than under RT (Fig. 5b). In the PN-BF rotation, no differences in $\mathrm{mSOC}$ among tillage treatments were observed in any soil depth. No differences were observed in mSOC between cropping systems in any soil depth (Fig. 5b).

\section{Impact of agro-technological Options on} Soil Health

Healthy soils are also necessary for the maintenance of soil biodiversity, which in turn takes care of many pests and diseases of crops in a holistic manner. Healthy soils free of contamination enhance ecological wellbeing within the community. However, information on integrated soil management approaches (nutrient management, water management, farming systems, cropping systems and rotations, crop recycling, waste utilization, etc.) to be followed for different agro- ecological conditions should be provided to farmers. Developing unified and most acceptable soil quality indicators specific to soil types, and agro-ecosystems

Adequate availability of organic carbon and other nutrients for soil organisms is the greatest challenge in the biological component of soil. Soil biotas are highly sensitive to any disturbance in soils and act as early indicators of soil deterioration. Nutrient depletion and the absence of nutrient replenishment mean the soil population suffers stress, which affects soil function and crop productivity. Soil contamination by chemicals and pollutants also affects the soil biological functions, which is reflected in poor crop establishment and productivity. Soil factors along with management factors affect the crop performance by way of modifying the rhizosphere environment, which modifies the root exudate's characteristics and affects the microbial function and diversity along with alterations in nutrient transformations and uptake (Fig. 6b).

Several indicators are used for the assessment of soil quality or soil health (Table 1). Soil indicators such as soil structure, water infiltration (Reynolds et al., 2009), bulk density (Pattison et al., 2008) rooting depth (Arias et al., 2005) and soil surface cover (Dalal and Moloney 2000), etc., were used to assess the soil physical quality. Soil physical properties provide information related to water and air movement through the soil, as well as conditions affecting germination, root growth 
and erosion processes. Many soils' physical properties thus form the foundation of other chemical and biological processes, which may be further governed by climate; landscape position and land use (Allen et al., 2011). Soil $\mathrm{pH}$ is considered one of the dominant chemical indicators of soil health, identifying trends for a range of biological and chemical functions including acidification, salinization, crop performance, nutrient availability and cycling, and biological activity (Dalal and Moloney 2000).

The amount of mineralizable organic matter (potentially mineralizable carbon and nitrogen) in soil is an indicator of organic matter quality, acting as the interface between autotrophic and heterotrophic organisms during the nutrient cycling process (Haynes 2008). Microbial biomass, the living component of SOM, is considered the most labile $\mathrm{C}$ pool in soils and a sensitive indicator of changes in soil processes, with links to soil nutrient and energy dynamics (Srivastava et al., 2014). Soil enzymes (urease, dehydrogenase, glucosidase, phosphatase, arylsulfatase, etc.) involved in soil nutrient transformations were also used as indicators of soil health by many researchers (Ashutosh Kumar et al., 2014). Microorganisms play a key role in ecologically important bio- geochemical processes (Kennedy 1999). Furthermore, microbiological properties are the most sensitive and rapid indicators of perturbations and land- use changes, as they develop in response to constraints and selection pressures in their environment (Kuramae et al., 2012).

Soil health is also under tremendous pressure from a few emerging problems which are reported to reduce the agricultural productiveness of soils (Fig. 6a). Land diversification and its associated soil degradation is a sustainability issue in many developing and developed countries. As population expands and urbanization spreads, less area per capita becomes available under cultivation with a consequent reduction in agricultural production. Clearing or use of agricultural lands for human activity has made way for soil degradation. Moreover, much land which originally accommodated food crops has been or is being converted to meet future demands of fuel and fibre, which will subsequently degrade the soil properties and associated functions, leading to a loss of soil biodiversity.

Soil health or quality in terms of physical, chemical and biological properties can be improved or restored by different ways with human intervention (Fig. 6b). Soil organic carbon influences physical, chemical, and biological functions and serves as an important sink and source of main plant nutrients.

Soil organic carbon content, aggregation status, total porosity, pore size distribution, bulk density, dispersion ratio, and soil strength were correspondingly improved with crop residue incorporation (Bijay-Singh et al., 2008). Soil organic carbon content also influences the crop response to applied nutrients. Beneficial effects of rice straw $(5 \mathrm{t}$ $\mathrm{ha}^{-1}$ ), applied in situ 20 days before wheat sowing, in conjunction with $120 \mathrm{~kg} \mathrm{~N}^{-1}$ ( $\mathrm{C}: \mathrm{N}$ ratio of $15: 1$ ) have been observed on wheat yield (Sidhu and Beri, 2005).

The addition of organic materials in sufficient amounts to soil is important for improving soil health as the organic substrates influence the microbial population in the soil, which is responsible for nutrient transformations resulting in the availability of nutrients, particularly N, P, and S. Incorporation of crop residues increased the population of aerobic bacteria and fungi while burning decreased it (Beri et al., 1992). Kahlown et al., (2002) reported that precision land leveling improved 
the performance of RW and water productivity in non-puddled soil, with no-till surface seeding and seeding on permanent beds compared with conventional tillage.

Inclusion of certain crops in sequential and intercropping systems has been found to reduce nutrient and water needs and the population of some obnoxious weeds to a considerable extent, thereby reducing herbicide needs to a great extent in areas where such weeds have assumed alarming proportions. Continuous cultivation of crops having similar management practices allows certain weed species to become dominant in the cropping system and, over time, these weed species become hard to control. In addition, continuous cropping can negatively interact with conservation agriculture systems and shift the weed flora toward a troublesome composition.

Rotating crops having divergent and distinct morphologies, growth habits, life cycles, differing cultural practices, and nutrient and water needs can all potentially affect the community composition and distribution of weeds. Increased fertilizer $\mathrm{N}$-use efficiency through improved management in a diversified crop can reduce the potential for nitrate contamination of groundwater. Inclusion of legumes in cropping systems has been found to be effective in reducing nitrate leaching in lower profiles. Legumes can play an important role in conserving groundwater and soil water. However, profitability of legumes has remained too low in comparison with rice and wheat (Joshi, 2003).

Site-specific nutrient management, which takes these factors into consideration, is needed to ensure balanced and optimum nutrient use, improvement in crop productivity, and higher nutrient-use efficiency. The use of a chlorophyll meter and leaf color chart is being advocated to apply the required amount of $\mathrm{N}$ (Turner and Jund, 1991). Wheat yield increased by $20 \%$ when 30 $\mathrm{kg} \mathrm{N} \mathrm{ha}{ }^{-1}$ was applied at a SPAD value of 42 at maximum tillering (Singh et al., 2002). Application of $50 \%$ of the recommended $\mathrm{N}$ dose with pre-sowing irrigation resulted in significantly higher wheat yield than its application at sowing (Sidhu et al., 1994). Probably $\mathrm{N}$ applied with pre-sowing irrigation was transported to the deeper layers of the soil and thus was not prone to loss via ammonia volatilization.

On coarse-textured soils, application of $\mathrm{N}$ in three equal splits at sowing and at first and second irrigation resulted in more efficient use of $\mathrm{N}$. For $\mathrm{P}$ and $\mathrm{K}$ management, nutrient omission technology that determines the soil supplying capacity and crop requirement for $\mathrm{P}$ and $\mathrm{K}$ in individual fields is suggested (Dobermann and Fairhurst, 2000). It is estimated that only $20-25 \%$ of the applied $\mathrm{P}$ is used by cereal crops and the rest is retained in the soil as residual P. In general, high water solubility of $\mathrm{P}$ will be required for alkaline and calcareous soils and for wheat more than for rice. P-use efficiency in the case of its placement below the soil surface and into the root zone of wheat was 1.5 times higher than when it was broadcast (Vig and Singh, 1983).

Balanced fertilization is the key to increasing the use efficiency of plant nutrients as it ensures the application of fertilizers in adequate amounts and correct ratios for optimum plant growth. Efficient nutrient management holds the key in RW double- or triple-cropping systems in which there is hardly any scope for keeping fields fallow between two crops. Also, nutrient recycling through organic manures is important, as shown for highly intensive triple-cropped ricewheat-corn or rice-wheat-mungbean systems (Timsina et al., 2006). Whenever feasible, inorganic fertilizers should be used in conjunction with organic manures. 
Fig.1 (a) Factors affecting soil health and crop productivity. BD: bulk density; HC: hydraulic conductivity; WHC: water holding capacity; OC: organic carbon; $\mathrm{Mb}-\mathrm{C}, \mathrm{N}, \mathrm{P}$, and S: microbial biomass carbon, nitrogen, phosphorus and sulphur; EC; electrical conductivity; CEC: cation exchange capacity; BS: base saturation; ESP: exchangeable sodium percentage; EMP: exchangeable magnesium percentage. Fig.1 (b) Constraints in soil management and crop production

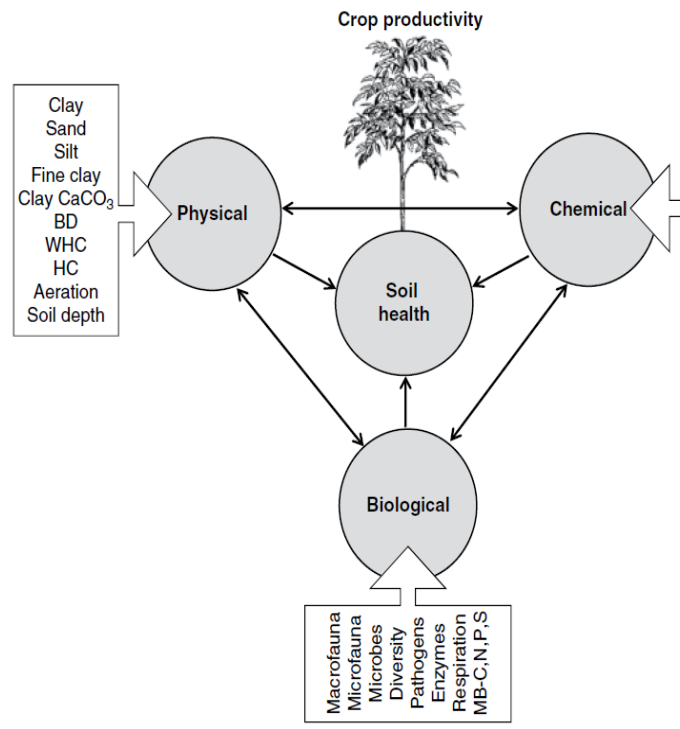

(a)
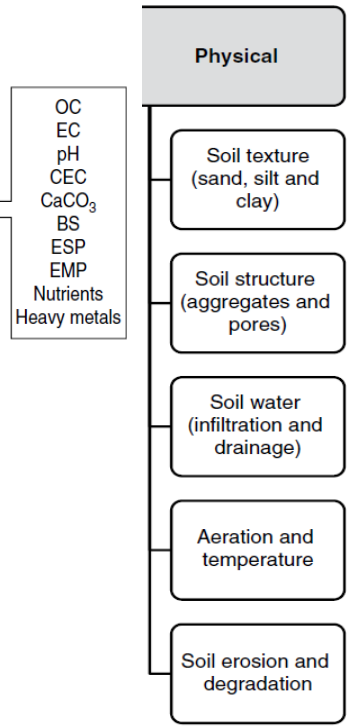

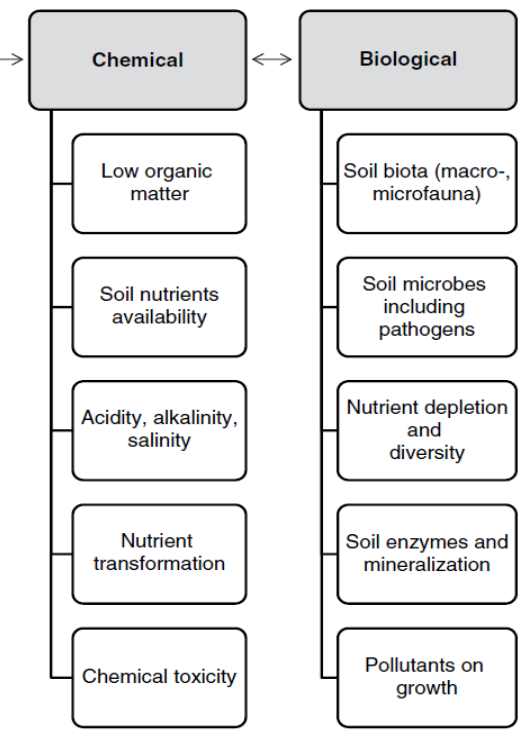

(b)

Fig.2 (a) Interactions between soil properties, crop management and crop productivity. BD: bulk density; HC: hydraulic conductivity; WHC: water holding capacity; OC: organic carbon; Mb-C,

$\mathrm{N}, \mathrm{P}$, and S: microbial biomass carbon, nitrogen, phosphorus and sulphur; EC; electrical conductivity; CEC: cation exchange capacity; BS: base saturation; ESP: exchangeable sodium percentage; EMP: exchangeable magnesium percentage. Fig.2 (b) Rhizosphere modification by physical, chemical and management factors

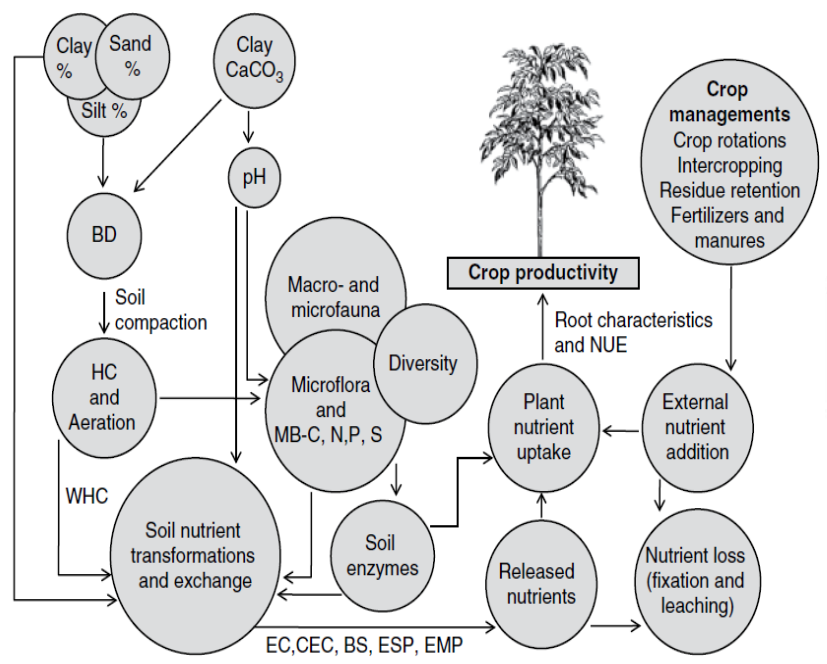

(a)

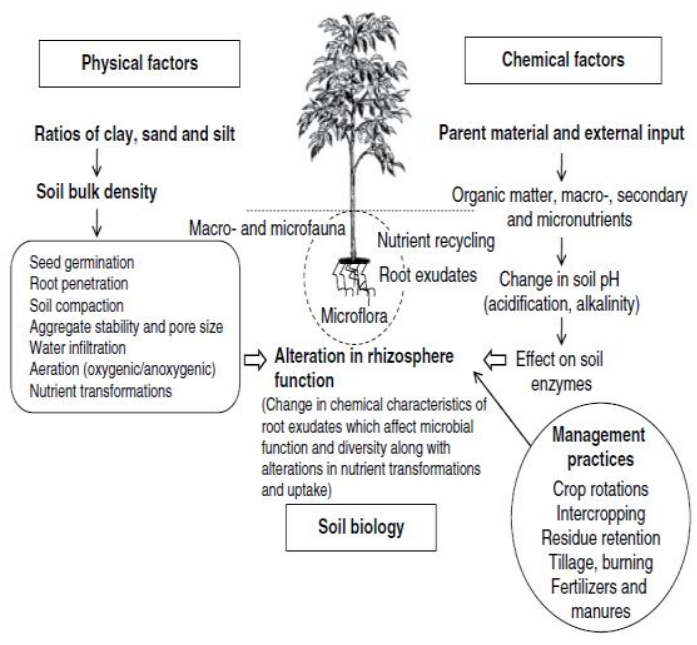

(b) 
Fig.3 (a) Water stable aggregate size distribution in different soil depths as influenced by tillage treatments. A, 0-5 cm. B, 5-10 cm. C, 10-20 cm. MP-R, moldboard plow without corn residue; $\mathrm{MP}+\mathrm{R}$, moldboard plow with corn residue; RT, rotary tillage with corn residue; NT, no-till with corn residue. Fig.3 (b) Sand-free aggregate total C concentration in different soil depths as influenced by tillage treatments. Fig.3 (c) Total soil carbon stock within aggregate size fractions in different soil depths as influenced by tillage treatments

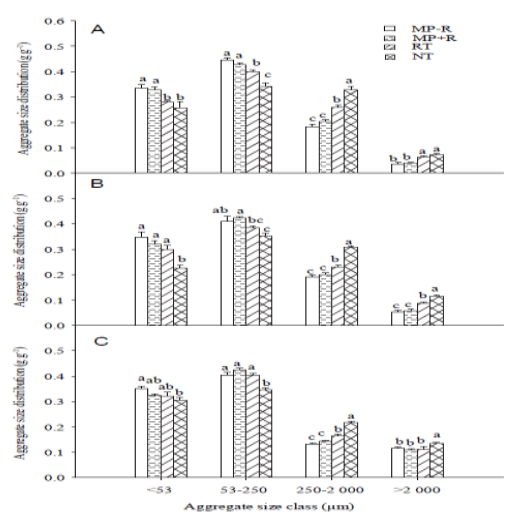

(a)

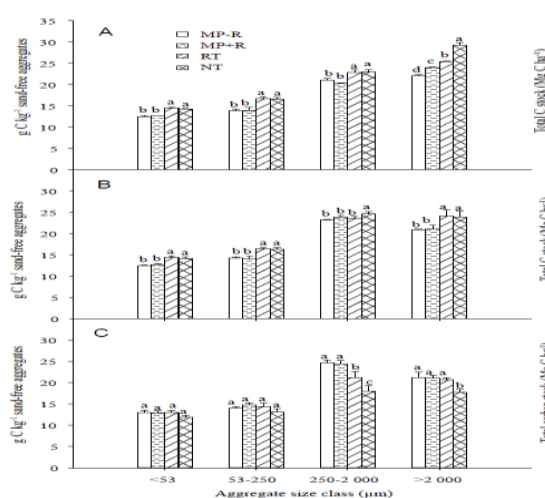

(b)

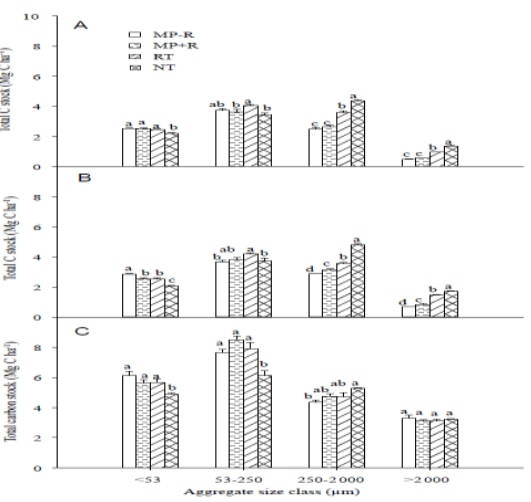

(c)

Fig.4 (a) Water-stable aggregate size distribution in 0- to 5-, 5- to 10-, and 10- to 20-cm soil layers as affected by cropping system (PN-BB, continuous barley system; PN-BF, barley-fallow rotation) and tillage (CT, conventional tillage; RT, reduced tillage; NT, no-tillage). Fig.4 (b) Sand-free aggregate $\mathrm{C}$ concentration distribution in 0- to 5-, 5- to 10-, and 10- to 20-cm soil layers as affected by cropping system (PN-BB, continuous barley system; PN-BF, barley-fallow rotation) and tillage (CT, conventional tillage; RT, reduced tillage; NT, no-tillage)

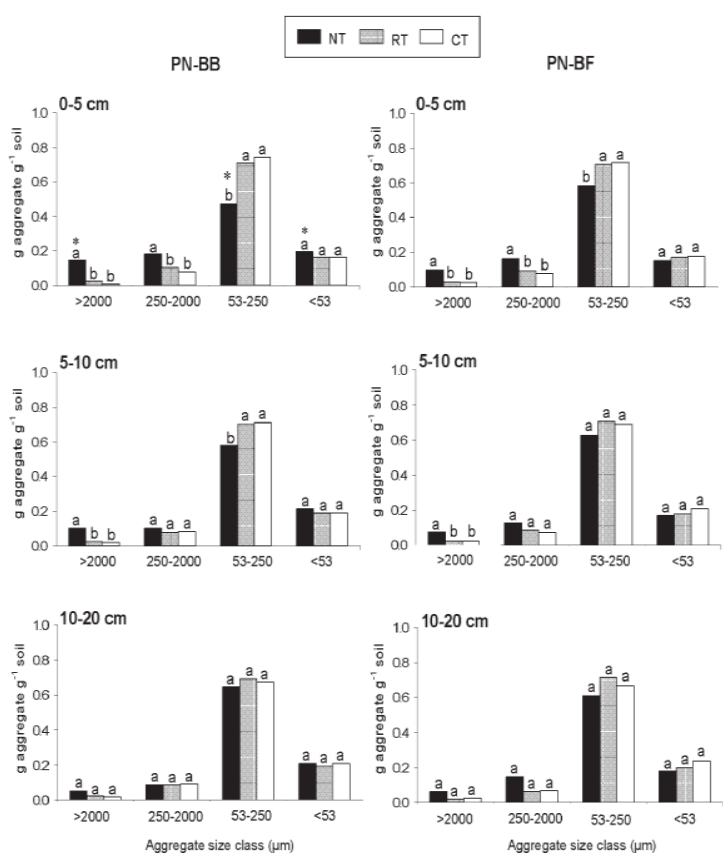

(a)

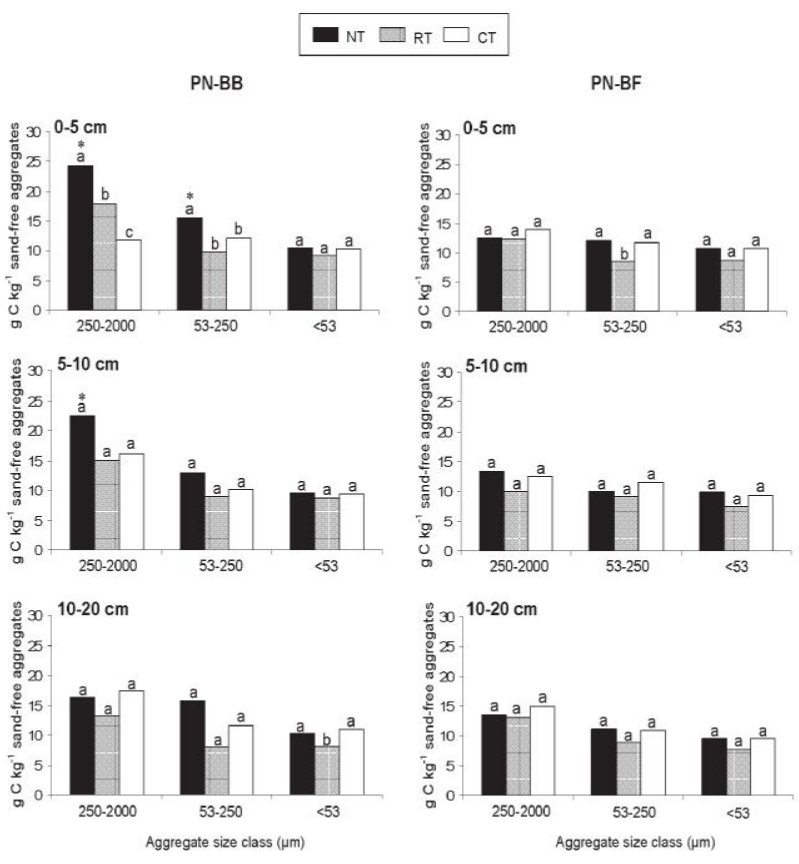

(b) 
Fig.5 (a) Distribution of sand-free intra-aggregate particulate organic matter C (iPOM C) in 0- to 5-, 5- to 10-, and 10- to 20-cm soil layers as affected by cropping system (PN-BB, continuous barley system; PN-BF, barley-fallow rotation) and tillage (CT, conventional tillage; RT, reduced tillage; NT, no-tillage). 250c: coarse $(250-2000 \mu \mathrm{m})$ iPOM C in small macro-aggregates (250$2000 \mu \mathrm{m})$; 250f: fine $(53-250 \mu \mathrm{m})$ iPOM C in small macro-aggregates $(53-250 \mu \mathrm{m})$; 53f: iPOM $\mathrm{C}(53-250 \mu \mathrm{m})$ in micro-aggregates $(53-250 \mu \mathrm{m})$. Fig.5 (b) Mineral associated soil organic C $(\mathrm{mSOC})$ in the 0- to 5-, 5- to 10-, and 10- to 20-cm soil layers as affected by cropping system (PN-BB, continuous barley system; PN-BF, barley-fallow rotation) and tillage (CT, conventional tillage; RT, reduced tillage; NT, no-tillage)

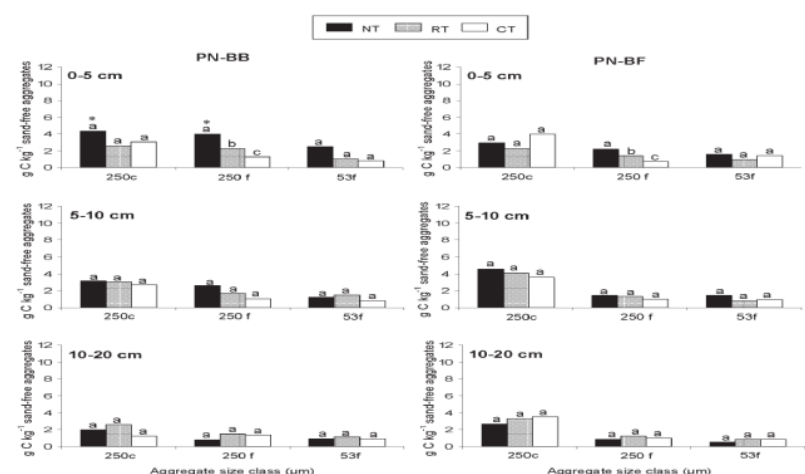

(a)

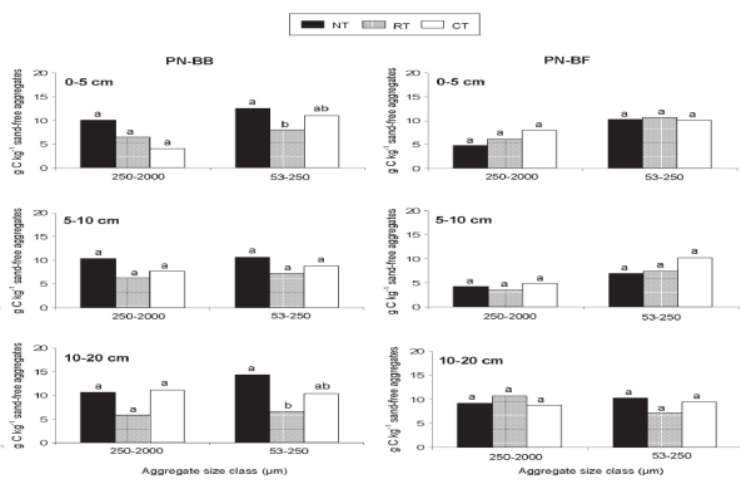

(b)

Fig.6 (a) Emerging sustainability challenges in soil health management. Fig.6 (b) Components of soil health management
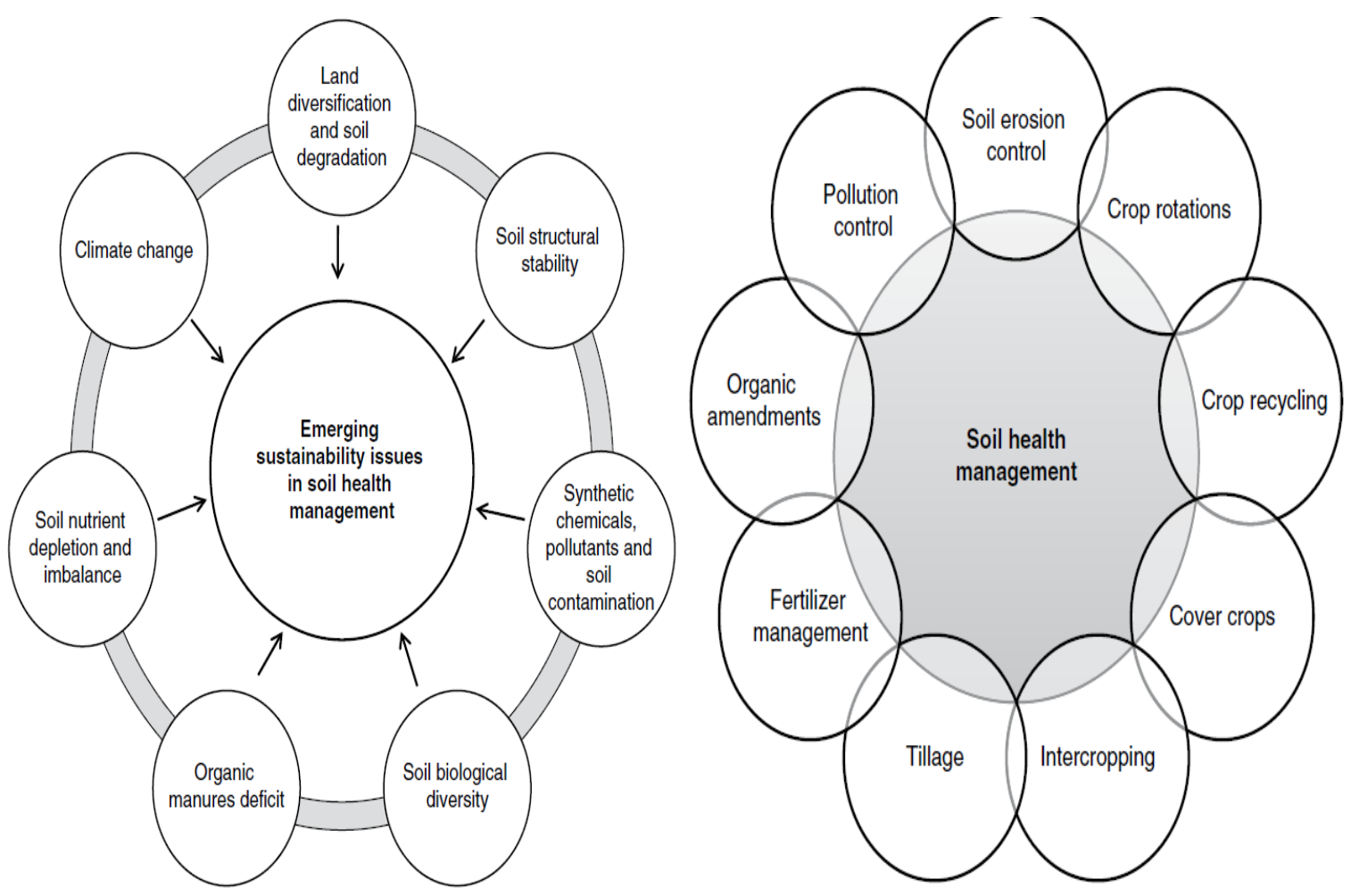
Fig.7 (a) Water foot prints for different crop production. Fig.7 (b) Contribution of different crops to the total water footprint of crop production Source: Mekonnen and Hoekstra, 2011

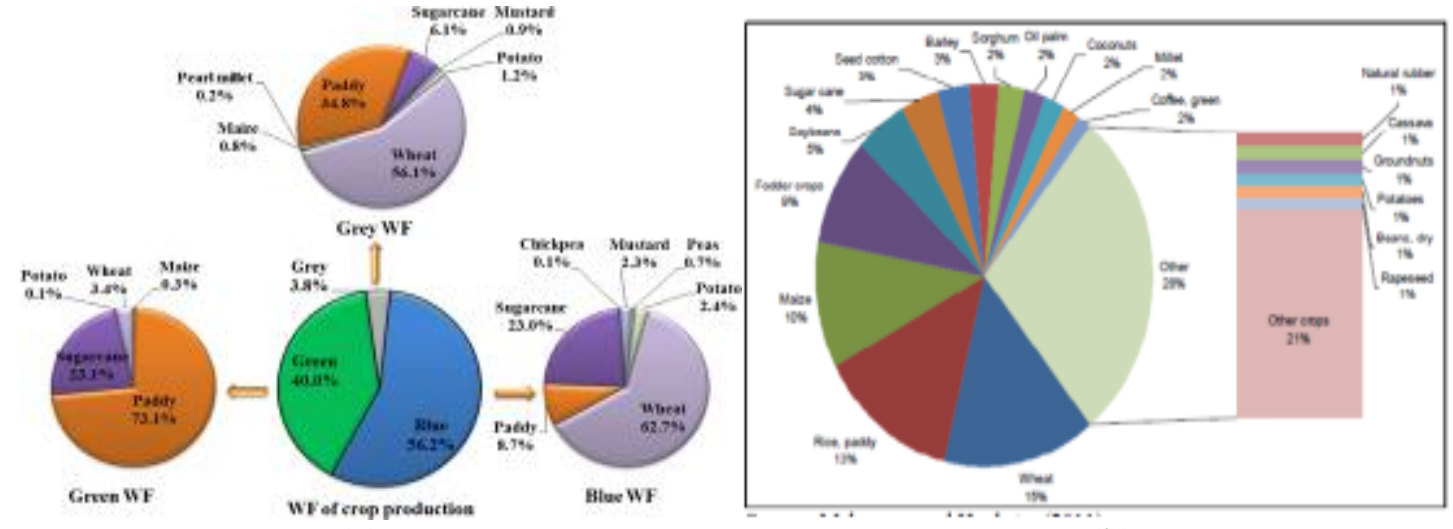

(a)

(b)

Fig.8 (a) Water footprint: Wheat

Fig.8 (b) Water footprint: Rice

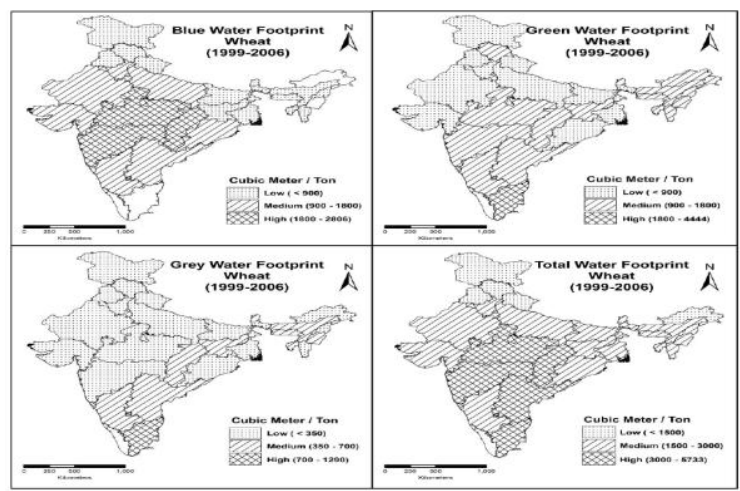

(a)

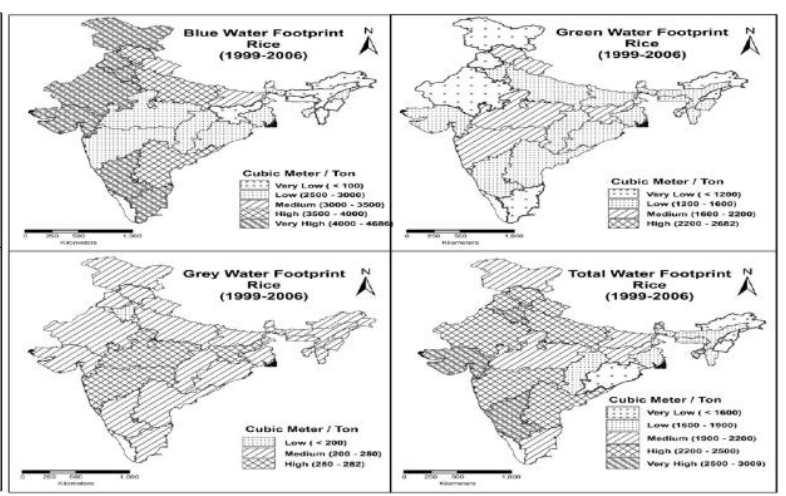

(b)

Fig.9 (a) Water footprint: Barley

Fig.9 (b) Water footprint:

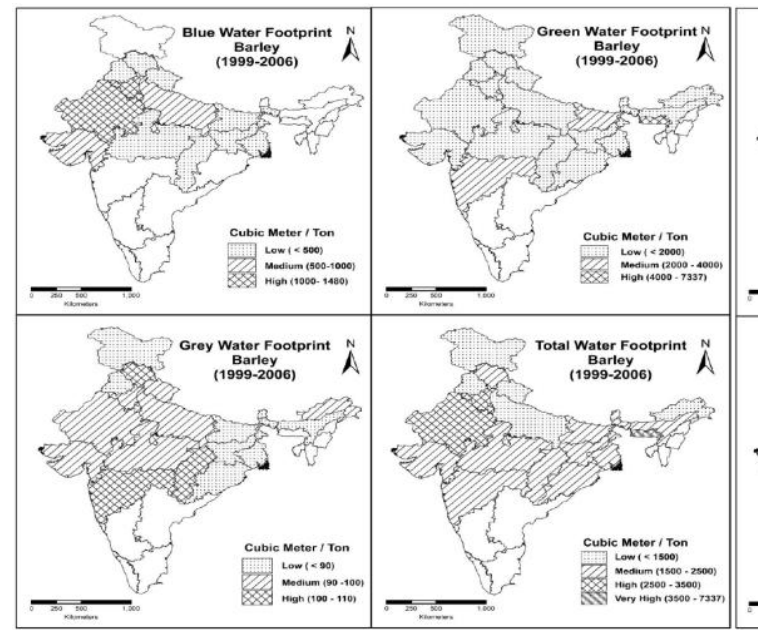

(a)

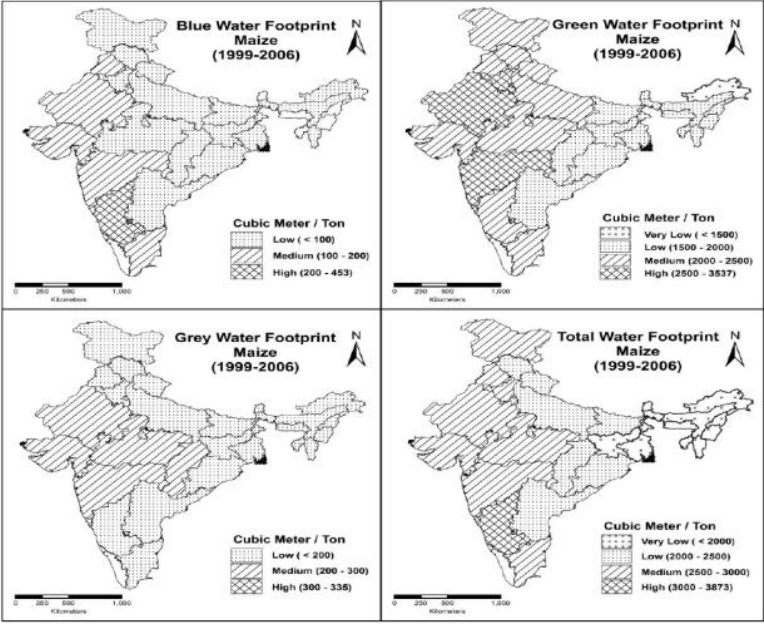

(b) 
Fig.10 (a) Water footprint: Sorghum

Fig.10 (b) Water footprint: Millets

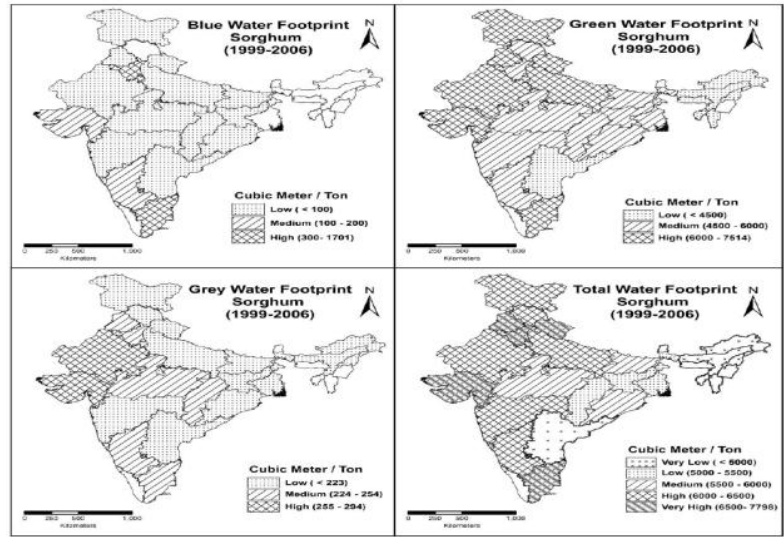

(a)

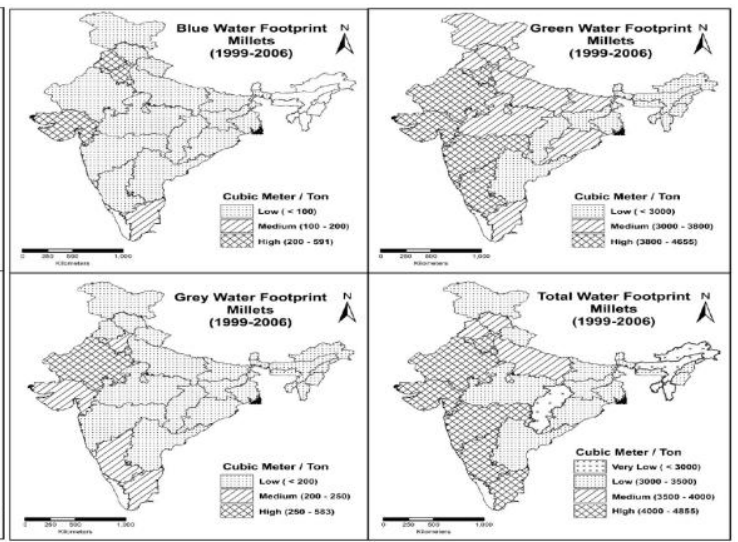

(b)

Table.1 Different indicators used in assessment of soil health

\begin{tabular}{|c|c|c|}
\hline Physical indicators & Chemical indicators & Biological indicators \\
\hline $\begin{array}{l}\text { Soil texture and } \\
\text { structure }\end{array}$ & $\mathrm{P}^{\mathrm{H}}$ & Soil organic carbon \\
\hline Bulk density & Electrical conductivity & Microbial biomass $(\mathrm{C}, \mathrm{N}, \mathrm{P}, \mathrm{S})$ \\
\hline Aggregate stability & $\begin{array}{l}\text { Major, secondary and minor } \\
\text { nutrients }\end{array}$ & Soil respiration \\
\hline Porosity & Carbonate content & Potentially mineralizable nitrogen \\
\hline Soil compaction & Leachable salts & Soil enzymes \\
\hline Soil crusting & Base saturation & Microbial population and diversity \\
\hline Stoniness & Carbon exchange capacity & $\begin{array}{l}\text { Mycorrhizal population and glomalin } \\
\text { content }\end{array}$ \\
\hline $\begin{array}{l}\text { Hydraulic } \\
\text { conductivity }\end{array}$ & $\begin{array}{l}\text { Exchangeable sodium and } \\
\text { magnesium percentage }\end{array}$ & $\begin{array}{l}\text { Macro-, meso- and microfauna } \\
\text { population }\end{array}$ \\
\hline $\begin{array}{l}\text { Available water } \\
\text { capacity }\end{array}$ & Toxic elements & Fluorescein diacetate hydrolysis \\
\hline Top soil depth & Colour & Microbial quotients \\
\hline
\end{tabular}

The conventional method of land preparation for transplanting or sowing in the RW system not only disturbs the soil environment but also leads to atmospheric pollution.

It is estimated that $2.6 \mathrm{~kg}$ of carbon dioxide $\left(\mathrm{CO}_{2}\right)$ is released to the atmosphere for each liter of diesel fuel consumed (Erenstein and Laxmi-Vijay, 2008). About 1501 of diesel are consumed per hectare per annum to run a tractor for field preparation and to pump water for irrigation in a conventional system, which amounts to emissions of about $400 \mathrm{~kg}$ $\mathrm{CO}_{2}$ per hectare per annum.

Thus, the farming practices used for RW cultivation over the years have changed the soil structure and nutrient availability, and increased dependence on synthetic fertilizers and machinery. This has increased the cost of cultivation and affected the immediate environment. 
Declining soil health has become an important constraint to productivity in the region. Traditionally, land preparation constitutes the major cost of production of wheat in the transplanted RW production system due to repeated plowings needed to obtain desirable tilth and this practice also delays wheat sowing, thus affecting its productivity. The adoption of no-till, which is based on the principle of no or minimum soil disturbance, is considered vital for maintaining the productivity of the RW system (Gupta et al., 2005). The alternative establishment techniques for rice, such as dry DSR, have shown promise in different production environments in eastern U.P. and may alleviate many of the problems associated with puddled transplanted rice.

\section{Impact of agro-technological options on water footprints}

Recently, some of these problems have been overcome and agro-technology with respect to cultivars, sowing time, seeding rate, crop geometry, and weed, nutrient, and water management has been developed and deployed in the RW system, which resulted in similar or higher outputs (system productivity), with $25 \%$ less water and labor and timeliness in planting (Gathala et al., 2011). Sowing in the first fortnight of June, using 15-30 kg seed $\mathrm{ha}^{-1}$ at 2-3-cm soil depth (Mahajan et al., 2010) and 20-25-cm row spacing gives rice productivity of 6-8 $\mathrm{t} \mathrm{ha}^{-1}$ (Gansham and Singh, 2008). A seeding rate of $30 \mathrm{~kg} \mathrm{ha}^{-1}$ is adequate if weeds are properly controlled. Irrigation in dry DSR is applied after 3-5 days when the ponded water is infiltrated into the soil. Mahajan et al., (2011c) found that applied irrigation water increased by $28 \%$ in puddled transplanted rice compared with dry DSR. Bouman et al., (2005) reported that, on average, an aerobic field used $190 \mathrm{~mm}$ less water for land preparation and had 250-300 $\mathrm{mm}$ less seepage and percolation than a puddled field. Gopal et al., (2010) claimed that dry DSR saved irrigation water by eliminating the need to puddle the field. Similarly, Bhushan et al., (2007) realized irrigation water savings of $25 \%$ with no-till dry DSR compared with puddled transplanted rice when irrigation for both establishment methods was scheduled based on the appearance of hair-line cracks.

Humphreys et al., (2010) have also suggested several ways of saving water in rice in the RW system, including laser land leveling, alternate wetting and drying (AWD), delayed rice transplanting, shorter duration rice varieties, cultivation on raised beds, and replacing part of the rice area with other crops. The AWD practice can save 15 to $30 \%$ of irrigation water, without any adverse effect on rice yield (Sandhu et al., 1980). Adoption of dry DSR in the IGP can save a substantial amount of water required for rice (Mahajan et al., 2011c; Gopal et al., 2010; Naresh et al., 2017). Hira (2009) stated that, in cotton, a broad bed with spacing of $135 \mathrm{~cm}$ and planting cotton in furrows in paired rows increased yield by $44 \%$ and saved $40 \%$ of irrigation water compared with row spacing of $67.5 \mathrm{~cm}$ in flat-bed systems. Planting of potatoes on both sides of a narrow bed increased tuber yield $\left(24 \mathrm{t} \mathrm{ha}^{-1}\right)$ by $25 \%$ and saved $20 \%$ of irrigation water compared with the ridge-planting method $\left(20 \mathrm{t} \mathrm{ha}^{-1}\right)$.

Some area under wheat can also be replaced by oilseed (rapeseed-mustard) crops, which require only 2-3 irrigations. Oilseed crops offer an excellent opportunity for maximizing productivity under limited moisture availability (Reddy and Suresh, 2008). Sunflower crop productivity can be increased by more than $60 \%$ with limited irrigation at critical stages. The growing of rice-mustardmungbean for 1 year followed by rice-wheatmungbean in the succeeding 2 years registered an $11 \%$ savings of water, clearly 
favoring diversification of the RW system. In Bihar, a rice-potato-sunflower cropping system recorded higher rice equivalent yield, net returns, benefit: cost ratio, land-use efficiency, and production efficiency than a traditional rice-wheat-green manuring ( $S$. aculeata) cropping system (Fig. 7).

To reduce fatigue of the RW system, alternate crops such as oilseeds can be grown instead of wheat without hampering the profitability of the system. The area that is planted with wheat in the late season due to the late harvest of basmati rice could be shifted to sunflower or winter/spring corn. In Uttar Pradesh, where the RW system is important, it is possible to shift the part of the rice area located in higher landscapes to corn, or soybean, or pigeon pea. However, soybean as a pulse crop is not preferred by people in the region because of the typical "bean flavor" produced by soybean due to the lipoxygenase enzyme. Moreover, soybean and pigeon pea are susceptible to standing water, a situation normally experienced during the rainy season at any stage of growth of these crops and their cultivation also leads to late sowing of wheat.

The development of rice cultivars with weedsmothering characters, optimizing seeding rate, crop geometry, use of residue, and $\mathrm{N}$ management are some important aspects in managing weeds in DSR (Mahajan and Chauhan, 2011). Weed pressure during the early crop growing season can be reduced by adopting the stale seedbed technique, in which the seedbed can be prepared at least 710 days in advance of seeding with moisture ensured either by are then destroyed either by shallow cultivation or the use of non-selective herbicides such as paraquat or glyphosate. The use of herbicide may have the advantage of destroying weeds without disturbing the soil, thus reducing possibilities of bringing more seeds to the upper soil surface. In a study in India, the use of non-selective herbicide in a stale seedbed was more effective than mechanical weeding in DSR (Renu et al., 2000). The use of weedcompetitive crop cultivars can also help to suppress weeds in the RW system. A quickgrowing and early canopy cover enables a cultivar to compete better against weeds.

Research studies have shown that traditional tall cultivars, such as NERICA rice, exert an effective smothering effect on weeds (Prasad, 2011). Further, it has been observed that early-maturing cultivars and hybrids of rice also have a smothering effect on weeds due to vigor and they have a tendency of early canopy cover (Mahajan et al., 2011b). Mahajan and Chauhan (2011) observed that a paired-row planting (15e30-15 cm row-to-row spacing) pattern in dry DSR had a great influence on weeds compared with a normal row planting system $(23-\mathrm{cm}$ row-to-row spacing). Paired row planting greatly facilitates weed suppression by maintaining a dominant position over weeds through modification in canopy structure. In other dry DSR studies, reduced crop row spacing increased the crop's ability to compete with weeds for light (Chauhan, 2012). Chauhan and Johnson (2011b) reported that the critical periods (days) for weed control were fewer for a dry DSR crop in 15-cm rows than in 30cm rows.

Dry DSR warrants an intensive use of herbicides. Sequential application of pendimethalin (1 $\mathrm{kg}$ a.i. ha $\mathrm{ha}^{-1}$ as preemergence followed by post-emergence application of bispyribac-sodium $\left(25 \mathrm{~g}\right.$ a.i. ha ${ }^{-}$ $\left.{ }^{1}\right)$ proved effective for weed control in Punjab, India (Mahajan and Timsina, 2010). However, the continuous use of ALSinhibitor herbicides (e.g., bispyribac-sodium) may increase the problem of herbicide resistance against weeds in DSR in the near future. Therefore, appropriate and economical weed management technologies are required 
for the sustainable cultivation of DSR, which may include the stale seedbed technique, proper land preparation, preventive measures (such as using clean seeds), zero-till systems, the use of competitive cultivars, optimum seeding rate, paired-row planting, water and nutrient management, mulching, rotation of crop establishment methods, and the use of suitable chemicals at the right time.

Naresh et al., (2017) the water footprint of rice consumption in a nation is calculated by aggregating the water footprints in the regions where the rice consumed in a nation is grown by using a higher spatial resolution. In India water foot print of per unit and total rice production and percolation was $1403 \mathrm{~cm}^{3}$ ton $^{-1}$ ) and 432.9 (billion $\mathrm{m}^{3} \mathrm{yr}^{-1}$ ). The percapita water footprint of rice consumption is quite high in Thailand (547 $\left.\mathrm{m}^{3} \mathrm{cap}^{-1} \mathrm{yr}^{-1}\right)$ compared to India $\left(239 \mathrm{~m}^{3} \mathrm{cap}^{-1} \mathrm{yr}^{-1}\right)$, with their water footprints related to rice consumption 63,364 and 250,305 $\left(\mathrm{Mm}^{3} \mathrm{yr}^{-1}\right)$, respectively. One cup of coffee needs 140 liters of water; 1 liter of milk needs 1000 liters of water; $1 \mathrm{~kg}$ of wheat needs 1350 liters of water; $1 \mathrm{~kg}$ of rice needs 3000 liters of water and $1 \mathrm{~kg}$ maize needs 900 liters of water. Ding et al., (2018) reported that the grain yield-based WF ranged between 1.08 and 1.80, 0.90 and 1.38, 1.71 and 2.58, 1.94 and $4.28,1.47$ and 2.37 , and 1.39 and $1.79 \mathrm{~m}^{3}$ $\mathrm{kg}^{-1}$; whereas the protein yield-based WF ranged between 7.69 and 10.44, 8.27 and $16.47,3.79$ and $7.75,4.86$ and $11.17,5.09$ and 7.42 , and 5.51 and $10.69 \mathrm{~m}^{3} \mathrm{~kg}^{-1}$ for spring wheat, barley, canola, sunflower, lentils, and chickpea, respectively. All the WFs of crops generally decreased with time, which could be attributed to precipitation factors.

Mekonnen and Hoekstra (2011) revealed that the average water footprint for cereal crops is $1644 \mathrm{~m}^{3}$ ton $^{-1}$, but the footprint for wheat is relatively large $\left(1827 \mathrm{~m}^{3}\right.$ ton $\left.^{-1}\right)$, while for maize it is relatively small $\left(1222 \mathrm{~m}^{3}\right.$ ton $\left.^{-1}\right)$.
The average water footprint of rice is close to the average for all cereals together. Sugar obtained from sugar beet has a smaller water footprint than sugar from sugar cane. Besides, the blue component in the total water footprint of beet sugar $(20 \%)$ is smaller than for cane sugar $(27 \%)$ and for vegetable oils we find a large variation in water footprints: maize oil $2600 \mathrm{~m}^{3}$ ton $^{-1}$; cotton-seed oil 3800 $\mathrm{m}^{3}$ ton $^{-1}$; soybean oil $4200 \mathrm{~m}^{3}$ ton $^{-1}$; rapeseed oil $4300 \mathrm{~m} 3$ ton $^{-1}$; palm oil $5000 \mathrm{~m}^{3}$ ton $^{-1}$; sunflower oil $6800 \mathrm{~m}^{3}$ ton $^{-1}$; ground-nut oil $7500 \mathrm{~m}^{3}$ ton $^{-1}$; linseed oil $9400 \mathrm{~m}^{3}$ ton $^{-1}$; olive oil $14500 \mathrm{~m}^{3}$ ton $^{-1}$; castor oil $24700 \mathrm{~m}^{3}$ ton $^{-1}$ (Fig. 4b)

Mohd. Suhail, (2017) observed that total average WFP consumption of Indian states are much higher for Sorghum (6026), Soybeans (4410), Maize (2537), Barley (2124), Wheat (2100) and Rice (2070) than the global total WFP average of 3048, 2145, 1222, 1423, 1827 and 1673 cubic meter per ton, respectively. However, spatial variability also estimated among Indian states, Utter Pradesh $\left(28306 \mathrm{~m}^{3} /\right.$ ton $)$ is the highest total WFP consumer followed by Himachal Pradesh (27889 $\mathrm{m}^{3} /$ ton), Uttarakhand (27809 $\mathrm{m}^{3} /$ ton), Tamil Nadu (27739 $\mathrm{m}^{3} /$ ton) Bihar (26960 $\mathrm{m}^{3} /$ ton), Gujarat $\left(26692 \mathrm{~m}^{3} /\right.$ ton $)$, Maharashtra (26460 $\mathrm{m}^{3} /$ ton), Haryana (26337) and Rajasthan $\left(25860 \mathrm{~m}^{3} /\right.$ ton $)$.

While, lowest total WFP consumption are embodied in North-Eastern states, except Meghalaya as an average of $1900 \mathrm{~m}^{3} / \mathrm{ton}$, followed by Andhra Pradesh (18381 $\mathrm{m}^{3} /$ ton), Orissa (20459 $\mathrm{m}^{3} /$ ton), Chhattisgarh (22074 $\mathrm{m}^{3} /$ ton), Punjab (22323 $\mathrm{m}^{3} /$ ton), Jharkhand (22454 $\mathrm{m}^{3} /$ ton), Jammu and Kashmir (23760 $\mathrm{m}^{3} /$ ton), Karnataka (24100 $\mathrm{m}^{3} /$ ton), Madhya Pradesh (24432 $\mathrm{m}^{3} /$ ton) and West Bengal (24467 $\mathrm{m}^{3} /$ ton). Possible reason for such variability could accompany by agriculture practices, cropping patterns, soil properties, climates and many other factors. 
Apart from spatial variability in total WFP, commodity-wise variability also exists for selected crops. Significantly Tamil Nadu contributes highest in wheat $\left(4401 \mathrm{~m}^{3} /\right.$ ton $)$ WFP. Almost 76 per-cent of total WFP contributed by green WFP in Tamil Nadu that is supplied with soil moisture and remaining amount contributed by fertilizer application used. Total wheat related WFP of Madhya Pradesh $\left(4151 \mathrm{~m}^{3} /\right.$ ton $)$ is the second highest after Chhattisgarh ( $4133 \mathrm{~m}^{3} /$ ton), Maharashtra (4032 $\mathrm{m}^{3} /$ ton), Andhra Pradesh (3004 $\mathrm{m}^{3} /$ ton), Karnataka (2747 $\mathrm{m}^{3} /$ ton), Gujarat (2504 $\mathrm{m}^{3} /$ ton) and Rajasthan (2414 $\mathrm{m}^{3} /$ ton) (Fig. 8 a). These states of India are consuming more water in wheat production as compared to global average $\left(1827 \mathrm{~m}^{3} /\right.$ ton $)$; the possible reason to this could be rain-fed agriculture and large growing season of the crops.

However, main wheat producing states like Jammu and Kashmir (1228 $\mathrm{m}^{3} /$ ton), Punjab (1261 $\mathrm{m}^{3} /$ ton), Assam (1696 $\mathrm{m}^{3} /$ ton), Uttar Pradesh (1702 $\mathrm{m}^{3} /$ ton), Haryana (1722 $\mathrm{m}^{3} /$ ton $)$ Bihar (1728 $\mathrm{m}^{3} /$ ton $)$ and West Bengal (1734 $\mathrm{m}^{3} /$ ton) are much below than the global average of WFP.

Moreover, the average WFP for Rice also varies significantly (Fig. 8b), as Haryana $\left(2657 \mathrm{~m}^{3} /\right.$ ton $)$ is the largest WFP consumer followed by Gujarat $\left(2551 \mathrm{~m}^{3} /\right.$ ton $)$, Karnataka (2518 $\mathrm{m}^{3} /$ ton), Uttarakhand $\left(2495 \mathrm{~m}^{3} /\right.$ ton $)$, Maharashtra (2324 $\mathrm{m}^{3} /$ ton), Andhra Pradesh (2282 $\mathrm{m}^{3} /$ ton), Uttar Pradesh $\left(2274 \mathrm{~m}^{3} /\right.$ ton $)$, Punjab (2228 $\mathrm{m}^{3} /$ ton), Bihar $\left(2117 \mathrm{~m}^{3} /\right.$ ton $)$, Jammu and Kashmir (2091 $\mathrm{m}^{3} /$ ton), and Tamil Nadu (2070 $\mathrm{m}^{3} /$ ton $)$. These are the states where the total WFP consumption for rice is not only much high than India average (2070 m3/ton) but also global average (1673 $\mathrm{m}^{3} /$ ton). In addition, the states like West Bengal (1745 $\mathrm{m}^{3} /$ ton), Assam $\left(1626 \mathrm{~m}^{3} /\right.$ ton $)$, Orissa $\left(1553 \mathrm{~m}^{3} /\right.$ ton $)$, and few North-Eastern states are performing well as compare to the national average.
While in the case of barley (Fig. 9a), Rajasthan has highest WFP with an amount of $2846 \mathrm{~m}^{3} /$ ton. The second highest WFP added by Haryana $\left(2675 \mathrm{~m}^{3} /\right.$ ton $)$ after Gujarat and Maharashtra with equal contribution with an amount of $2492 \mathrm{~m}^{3} /$ ton. States like Madhya Pradesh (2227 $\mathrm{m}^{3} /$ ton) and Bihar (2133 $\mathrm{m}^{3} /$ ton) along with above states consume more water than national average (2124 $\mathrm{m}^{3} /$ ton). Remaining states like, West Bengal (2005 $\mathrm{m}^{3} /$ ton), Jharkhand (1993 $\mathrm{m}^{3} /$ ton), Chhattisgarh (1991 $\mathrm{m}^{3} /$ ton), Orissa (1976 $\mathrm{m}^{3} /$ ton $)$ and Uttar Pradesh $\left(1480 \mathrm{~m}^{3} /\right.$ ton $)$ are below the national average while Punjab $\left(1004 \mathrm{~m}^{3} /\right.$ ton $)$ is the only states below the world average as well as national average in terms of embodied water in Barley crops.

However, Karnataka (3072 $\mathrm{m}^{3} /$ ton), Rajasthan (2912 $\mathrm{m}^{3} /$ ton), Maharashtra (2911 $\mathrm{m}^{3} /$ ton), Haryana (2806 $\left.\mathrm{m}^{3} / \mathrm{ton}\right)$, Gujarat (2805 $\mathrm{m}^{3} /$ ton), Tamil Nadu (2778 $\mathrm{m}^{3} /$ ton) and Punjab $\left(2590 \mathrm{~m}^{3} /\right.$ ton $)$ are exceeding than the national average $\left(2537 \mathrm{~m}^{3} /\right.$ ton $)$ as well as world average $\left(1222 \mathrm{~m}^{3} /\right.$ ton $)$, in terms of total WFP embodied in Maize crop (Fig. 9b). While, Madhya Pradesh (2516 $\mathrm{m}^{3} /$ ton), Uttarakhand (2491 $\mathrm{m}^{3} /$ ton), Uttar Pradesh (2408 $\mathrm{m}^{3} /$ ton), Bihar (2098 $\mathrm{m}^{3} /$ ton $)$, Andhra Pradesh $\left(2073 \mathrm{~m}^{3} /\right.$ ton $)$, Orissa $\left(2064 \mathrm{~m}^{3} /\right.$ ton $)$, Jharkhand (1982 $\mathrm{m}^{3} /$ ton), West Bengal (1911 $\mathrm{m}^{3} /$ ton) and North-Eastern states are below than the national average but higher than global average as shown in figure. The possible reason for such variation could be growing the period of the crop and high potential evaporation rate as compare to other Maize growing region of the world.

Another principal crop of India is millets that grown throughout the country with various potential and third largest water intensive crop after Sorghum and Soybean in terms of water consumption for a ton yield. It is significant to note that entire India is much below than the global average in Millets 
related WFP whether Blue, Green or Grey. The states above the national average (4029 $\mathrm{m}^{3} /$ ton) estimated are Karnataka (4204 $\mathrm{m}^{3} /$ ton), Rajasthan (4145 $\mathrm{m}^{3} /$ ton), Maharashtra (4130 $\mathrm{m}^{3} /$ ton) and Tamil Nadu (4126 $\mathrm{m}^{3} /$ ton). Nonetheless, Punjab (3981 $\mathrm{m}^{3} /$ ton), Uttar Pradesh (3552 $\mathrm{m}^{3} /$ ton), Uttarakhand (3405 $\mathrm{m}^{3} /$ ton), Madhya Pradesh (3370 $\mathrm{m}^{3} /$ ton), Bihar $\left(3359 \mathrm{~m}^{3} /\right.$ ton $)$, Orissa (3266 $\mathrm{m}^{3} /$ ton $)$, Andhra Pradesh $\left(3220 \mathrm{~m}^{3} /\right.$ ton $)$, West Bengal $\left(3014 \mathrm{~m}^{3} /\right.$ ton $)$ and North-Eastern state (average $2950 \mathrm{~m}^{3} /$ ton) are embodied less than the national average WFP for Millets (Fig. 10a).

In addition, most of the states are higher than the global average in Sorghum related WFP. Tamil Nadu (7571 $\mathrm{m}^{3} /$ ton), Haryana (7317 $\mathrm{m}^{3} /$ ton), Gujarat (7152 $\mathrm{m}^{3} /$ ton), Punjab (6682 $\mathrm{m}^{3} /$ ton $), \quad$ Uttarakhand (6554 $\mathrm{m}^{3} /$ ton $)$, Rajasthan (6391 $\mathrm{m}^{3} /$ ton), Uttar Pradesh (6371 $\mathrm{m}^{3} /$ ton), Maharashtra (6154 $\mathrm{m}^{3} /$ ton) and Karnataka $\left(6031 \mathrm{~m}^{3} /\right.$ ton $)$ are higher than the national average $\left(6026 \mathrm{~m}^{3} / \mathrm{ton}\right)$ of Sorghum related WFP (Fig. 10b).

This article has identified several key issues and opportunities relevant to current production and future sustainability of RW that warrant further research efforts. Efforts are needed to improve nutrient-use efficiency and total factor productivity by maintaining or improving soil health and improving wateruse efficiency. With the rising cost and nonavailability of labor, mechanization will become even more important in the future.

An overall productivity improvement of cropping systems is necessary to meet future food demand and to ensure that natural resources are conserved. The results study confirmed the viewpoint that combining and simultaneously applying best management and compatible conservation agriculture practices as technological interventions is crucial for optimizing resource use efficiency and maximizing productivity benefits in the rice-based cropping system. Agrotechnological options for introducing maize with potato as an intercrop in place of wheat in the winter season increased economic returns. Including a legume such as mungbean or cowpea as a summer crop and leaving residues on the soil surface had positive effects on irrigation water savings and the productivity of the succeeding rice crop. Retaining crop residues on the soil surface or incorporating residues into the soil provides a solution to atmospheric pollution and degradation of soil quality that is caused by burning of residues in the field.

An agro-technological option (including components of CA) together with increasing cropping intensity and crop substitution (diversification) should become a principal direction for increasing system productivity and sustainability in Sub-humid Purvanchal Region, Uttar Pradesh. However, this will require equally strong emphases on development and introduction of appropriate planting and harvesting equipments and building mechanization capacity of farmers.

Given that proven technologies exist to ameliorate many of the problems encountered in underutilized lands and targeting appropriate technologies in this way can help ensure that maximum benefits are obtained from scarce resources. With increasing pressure on natural resources, particularly land and water, decreasing labor availability, changing economic and social obligations, impact on environment of the current farming practices, increasing mechanization, etc., the RW system is under pressure to fulfill the increasing food needs of the rising population of more than 1.6 billion people forecast by 2050. There is little scope for further expansion of area under RW, an increase in cropping intensity, and reclamation of degraded soils. 


\section{References}

Allen, D. E, Singh, B. P. and Dalal, R. C. (2011). Soil health indicators under climate change: A review of current knowledge. In: B. P. Singh et al., (eds.), Soil Health and Climate Change. Berlin: Springer- Verlag: 25-45.

Arias, M. E., Gonzalez- Perez, F. J. and Gonzalez- Vila, A. S. B. (2005). Soil health: A new challenge for microbiologists and chemists. International Microbiology, 8: 13-21.

Ashutosh Kumar, Srivastava, A. K., Velmourougane, K. and Bhattacharyya, T. (2014). Urease activity and its kinetics in selected bench mark soils of Indo- Gangetic Plains. Proceedings of National Academy of Sciences, India, Section. B Biological Sciences, doi: 10.1007s 40011-014- 0352- 5.

Balasubramanian, V., Adhya, T.K., Ladha, J.K., 2012. Enhancing Eco-efficiency in the Intensive Cereal-based Systems of the Indo-gangetic Plains, In: Issues in Tropical Agriculture - Eco-efficiency: From Vision to Reality. CIAT Publication, Cali, Colombia, pp. 1-7.

Bhattacharyya, T. et al., (2014). Soil information system: Use and potentials in humid and semi- arid tropics. Current Science, 107(9): 1550-1564.

Bindraban, P. S. et al., (2012). Assessing the impact of soil degradation on food production. Current Opinion in Environmental Sustainability, 4: 47888.

Dalal, R. C. and Moloney, D. (2000). Sustainability indicators of soil health and biodiversity. In: P. Hale, A. Petrie, D. Moloney and P. Sattler (eds.), Management for Sustainable Ecosystems. Brisbane, Australia: Centre for Conservation Biology: 101-08.

Ding, D., Zhao, Y., Hui Guo, Hui., Li, X., Schoenau, J., and Si, B. 2018. Water
Footprint for Pulse, Cereal, and Oilseed Crops in Saskatchewan, Canada, Water 10, 1609; doi: 10.3390/ w 10111609

Doran, J. W. and Zeiss, M. R. (2000). Soil health and sustainability: Managing the biotic component of soil quality. Appl Soil Ecol, 15: 119-127.

Erenstein, O., Farooq, U., Malik, R.K., Sharif, M., 2007a. Adoption and Impacts of Zero Tillage as a Resource Conserving Technology in the Irrigated Plains of South Asia. Comprehensive Assessment of Water Management in Agriculture, Research Report 19. International Water Management Institute, Colombo. Sri Lanka.

Fuentes, A.J., Cantero-Martínez, C., López, M.V., Paustian, K., Denef, K., Stewart, C.E., and Arrúe, J.L. 2009. Soil Aggregation and Soil Organic Carbon Stabilization: Effects of Management in Semiarid Mediterranean Agroecosystems. Soil Sci. Soc. Am. J. 73: 1519-1529

Gathala, M., Ladha, J.K., Balyan, V., Saharawat, Y.S., Kumar, V., Sharma, P.K., Sharma, S., Pathak, H., 2011. Tillage and crop establishment affects sustainability of South Asian rice-wheat system. Agron. J. 103, 1-10.

Gathala, M.K., Timsina, J., Islam, Md., S, Krupnik, T.J, Bose, T.R, Islam, N, Rahman, M.M, Hossain, M.I, HarunAr-Rashid, Ghosh, A.K., Hasan, M.M.K., Khayer, M.A., Islam, M.Z., Tiwari, T.P., McDonald, A.J., 2016. Productivity, profitability, and energetics: a multi-criteria and multilocation assessment of farmers' tillage and crop establishment options in intensively cultivated environments of South Asia. Field Crops Res. 186, 3246.

Gathala, M.K., Timsina, J., Islam, S., Rahman, M., Hossain, I., Harun-Ar, Rashid, Ghosh, A.K., Krupnik, T.J., 
Tiwari, T.P., McDonald, A., 2015. Conservation agriculture based tillage and crop establishment options can maintain farmers' yields and increase profits in South Asia's rice-maize systems: evidence from Bangladesh. Field Crops Res. 172, 85-98.

Gopal, R., Kumar, R., 2010. Recent Advances in Resource Conserving Technologies for Rice. In: Rice Knowledge Management Portal (RKMP), 13 pages. Directorate of RiceResearch,Hyderabadwww.rkmp.co. in/sites/default/files/ris/research-themes/ Recent $\% 20$ Advances $\%$ 20in\%20Resource\% 20Conserving\% 20Technologies\%20 for\% 20Rice.pdf.

Gupta, R.K., Naresh, R.K., Hobbs, P.R., Jiaguo, Z., Ladha, J.K., 2003. Sustainability of post-green revolution agriculture: the rice-wheat cropping systems of the Indo- Gangetic Plains and China. In: Ladha, JK, et al., (Eds.), et al., Improving the Productivity and Sustainability of Rice-Wheat Systems: Issues and Impacts. ASA Spec. Publ. 65. ASA, CSSA and SSA, Madison, WI, pp. 1-25.

Haynes, R. J. (2008). Soil organic matter quality and the size and activity of the microbial biomass: Their significance to the quality of agricultural soils. In: Q. Huang, P. M. Huang and A. Violante (eds.), Soil Mineral- microbe- organic Interactions: Theories and applications. Berlin: Springer: 201-30.

Hobbs, P.R., Gupta, R.K., 2003. Resourceconserving technologies for wheat in the rice-wheat system. In: Ladha, JK, et al., (Eds.), et al., Improving the productivity and sustainability of ricewheat systems: issues and impacts. ASA Spec. Publ. 65. ASA, CSSA and SSA, Madison, WI, pp. 149-171.

Jat, R.K., Sapkota, T.B., Singh, R.G., Jat, M.L., Kumar, M., Gupta, R.K. 2014.
Seven years of conservation agriculture in a rice-wheat rotation of eastern Gangetic Plains of South Asia: yield trends and economic profitability. Field Crops Res. 164, 199-210.

Kennedy, A. C. (1999). Microbial diversity in agroecosystem quality. In: W. W. Collins and C. O. Qualset (eds), Biodiversity in Agroecosystems. Boca Raton, FL: CRC Press: 1-17.

Kuhn, N. J. (2007). Erodibility of soil and organic matter: Independence of organic matter resistance to interrill erosion. Earth Surface Processes and Landforms, 32: 794-802.

Kumar, V., Ladha, J.K., 2011. Direct seeding of rice: recent developments and future research needs. Adv. Agron. 111: 297313.

Kuramae, E. E., Yergeau, E., Wong, L. C. et al., (2012). Soil characteristics more strongly influence soil bacterial communities than land- use type. FEMS Microbiology Ecology, 79: 1224.

Lal, R. (2000). Soil management in the developing countries. Soil Sci, 165: 5772.

Lal, R. and Stewart, B. A. (1995). Soil management: Experimental basis for sustainability and environmental quality. Adv Soil Sci Series: 1-67.

Lambin, E. F. and Meyfroidt, P. (2011). Global land use change, economic globalization, and the looming land scarcity. Proc National Academy Sci USA, 108: 3465-72.

Lehman, R. M. et al., (2015). Understanding and enhancing soil biological health: The solution for reversing soil degradation. Sustainability, 7: 9881027.

Mekonnen, M. M. and Hoekstra, A. Y., 2011. The green, blue and grey water footprint of crops and derived crop products. Hydrology Earth Syst Sci, 15: 1577- 
1600.

Mohd. Suhail. 2017. Assessment of Water Footprint in Selected Crops: A State Level Appraisal, J. Geographical Studies, 1(1): 11-25.

Naresh, R.K., Jagdish Timsina, Ashish Dwivedi, Vineet Kumar, Vineet Singh, Shukla, A.K., Singh, S.P., and Gupta, Raj K. 2017. Water footprint of rice from both production and consumption perspective assessment using remote sensing under subtropical India: A review, Int J Chem Stu. 5(1): 343-350

Pattison, A. B., Moody, P. W., Badcock, K. A. et al., (2008). Development of key soil health indicators for the Australian banana industry. Appl Soil Ecol, 40: 155-64.

Royal Society (2009). Reaping the benefits: Science and the sustainable intensification of global agriculture. RS Policy document 11/09, issued: October 2009 RS1608.

Royal Society (2009). Reaping the benefits: Science and the sustainable intensification of global agriculture. RS Policy document 11/09, issued: October 2009 RS1608.

Sidhu, G. S. et al., (2014). Impact of management levels and land- use changes on soil properties in rice- wheat cropping system of the
Indo- Gangetic Plains. Curr Sci, 107(9): 1487-501.

Singh, N.P., Singh, R.P., Kumar, R., Vashist, A.K., Khan, F., Varghese, N., 2011. Adoption of resource conservation technologies in Indo-Gangetic Plains of India: scouting for profitability and efficiency. Agric. Econ. Res. Rev. 24: 15-24.

Singh, U.P., Singh, Y., Kumar, V., Ladha, J.K., 2009. Evaluation and promotion of resource-conserving tillage and crop establishment techniques in rice-wheat system of eastern India. In: Ladha, JK, et al., (Eds.), et al., Integrated crop and resource management in the rice-wheat system of South Asia. International Rice Research Institute (IRRI), Los Baños, Philippines, pp. 151-176.

Srivastava, A. K. et al., (2014). Impacts of agro- climates and land use systems on culturable microbial population in soils of the Indo- Gangetic Plains, India. Curr Sci, 107(9): 1464-9.

Zhang-liu, DU., Tu-sheng, Ren, Chun-sheng, HU, Qing-zhong, Zhang, and BlancoCanqui, H. 2013. Soil Aggregate Stability and Aggregate-Associated Carbon under Different Tillage Systems in the North China Plain, J Integ Agric. 12(11): 2114-2123

\section{How to cite this article:}

Robin Kumar, N. C. Mahajan, R. K. Naresh, S. S. Dhaliwal, Arvind Kumar, M. Sharath Chandra, Alok Kumar Pandey, S.F.A. Zaidi, Satendra Kumar, Rajendra Kumar, S.P. Singh and Sanjeev Kumar Gupta. 2019. Agro-technological Options for Scaling up Crop Productivity, Soil Health and Water Footprint in Rice based Cropping System in Sub-humid (Purvanchal) Region of Uttar Pradesh, India: A Review. Int.J.Curr.Microbiol.App.Sci. 8(07): 2679-2700. doi: https://doi.org/10.20546/ijcmas.2019.807.330 